\title{
ResearchArticle
}

\section{Molecular diagnosis, status and temporal incidence of papaya ringspot disease of papaya}

\author{
Upasna Priya, Monika Karn and Mohammad Ansar
}

\section{SUMMARY}

Papaya plant is severely affected by different viruses among them papaya ring spot virus is causing considerable yield loss leading to the complete failure of fruiting. Therefore, present investigation commenced with molecular diagnosis, current status and temporal incidence of disease. Various symptomatic plants gave positive amplification in one step RTPCR with both Potyvirus and PRSV CP gene specific primers indicating an amplicon of $\sim 330 \mathrm{bp}$ and $850 \mathrm{bp}$ bands, respectively. In leaf samples, 46 to 89 per cent RNA was found positive for PRSV infection. Whereas least infection of 13 per cent was found in seeds collected from infected fruits. The disease was observed at three different experimental plots which ranges from 49 to 75.3 per cent incidence. A rapid increase in the aphid population was noticed from middle of December to February. Further, maximum aphid population was noticed at experimental plot-1 (plant pathology) followed by plot-3 (IFS) with 5.48 and 5.14/plant. Periodic observation of the disease was assessed. The appearance of ringspot was noticed in first week of October with diverse symptom. It slowly increased upto middle of January and exponentially increased upto middle of May month with 65.3 per cent incidence. The peak aphid population was noticed in middle of February (20.5/plant) which was gradually declined upto 3.9/plant in May. The present information will helpful in understanding the epidemiology of ring spot disease and suitable management possibilities.

Key Words : Aphid, Papaya, RT-PCR, PRSV, Potyvirus

How to cite this article : Priya, Upasna, Karn, Monika and Ansar, Mohammad (2020). Molecular diagnosis, status and temporal incidence of papaya ringspot disease of papaya. Internat. J. Plant Sci., 15 (1): 55-60, DOI: 10.15740/HAS/IJPS/15.1/55-60, Copyright@ 2020: Hind Agri-Horticultural Society.

Article chronicle : Received : 16.11.2019; Revised : 11.12.2019; Accepted : 26.12.2019

\section{$\longrightarrow$ MEMBERS OF THE RESEARCH FORUM}

Author to be contacted :

Upasna Priya, Department of Plant Pathology, Bihar Agricultural

University, Sabour, Bhagalpur (Bihar) India

Email : upriya2014@gmail.com

Address of the Co-authors:

Monika Karn, Department of Plant Pathology, Dr. Y.S. Parmar

University of Horticulture and Forestry, Nauni, Solan (H.P.) India

Email : karn.monika1990@gmail.com

$-\frac{-}{\text { Mohammad Ansar, Department of Plant Pathology, Bihar Agricultural }}$ University, Sabour, Bhagalpur (Bihar) India 